\title{
Application of Mixed Methods Approach in Studies on Quality Assurance in Educational Institutions: A Systematic Review of Literature from 2005-2019
}

\author{
Edward Kigozi \\ Education University of Hong Kong
}

\begin{abstract}
The benefits of using mixed methods approach is particularly evident when studying a complex phenomenon that encompasses multiple initiatives and interactions, which is often the case in quality assurance research in educational institutions. The current systematic review of the literature was aimed at investigating the use of mixed methods in quality assurance research. The systematic review was conducted using three search engines Emerald Insight, ERIC, and Science direct on articles published between 2005 to 2019 in peer-reviewed journals. The review was guided by three research questions: (1) In what ways have different quality assurance researchers employed mixed methods approach in their studies? (2) What mixed methods approach have been applied by researchers while investigating quality assurance in educational institutions? (3) In what ways have researchers conceptualized the various research paradigms in quality assurance research? The review identified the various ways in which researchers applied mixed methods approaches/designs in quality assurance research; how researchers conceptualized the various research paradigms in quality assurance research; as well as the various mixed methods approaches/designs applied in quality assurance research. It was also concluded that, although there is a general increase in the use of mixed methods approaches in other fields, it's yet to be deeply applied in quality assurance research in educational institutions.
\end{abstract}

\section{Introduction}

Previously, mono-research designs of either qualitative or quantitative approaches have been famously well known and applied by most researchers, until recently mixed methods (the combination of qualitative and quantitative methods within a single study) has developed and emerged rapidly as an alternative research approach and methodology [13] [47] [50] [53]. Furthermore, next to the qualitative and quantitative approaches, it has been recognized as the third methodological movement in the field of social sciences, science and technology, medicine, and education [9][33][36]. Like in the other fields, due to the complexity of quality assurance in education institutions, the use of mixed methods (quantitative and qualitative methods in the same study) has been applied by some researchers investigating various aspects of quality assurance such as quality assurance practices, drivers of quality assurance implementation, policies and practices [15][42][24][27]. Although the studies conducted by the previous scholars have been empirical, systematic reviews of literature in quality assurance studies have also been conducted. For instance, a systematic review of literature on compliance of higher education institutions to quality assurance systems [20] the utilization of ICT in quality assurance and accreditation in higher education institutions in Europe [17] conducted a systematic on the major streams of research on the quality of student experience in higher education [46] and on exploring the notion of evidence-based policy' in the context of higher education quality assurance [2]. However, to date, a systematic review of literature on the use of a mixed-methods approach in studies on quality assurance in education institutions has not been conducted. Therefore, the major aim of conducting this systematic review is to investigate the use of mixed methods approach in quality assurance research articles published between 2010 and 2019 in various educational journals, this review strives to answer the following research questions: (1) In what ways have different quality assurance researchers employed mixed methods in their studies? (2) What mixed methods approaches/designs have been applied by researchers while investigating quality assurance in educational institutions? (3) In what ways have researchers conceptualized the various research paradigms in quality assurance research? By conducting this systematic review of literature, the researcher believes that it will raise awareness and added value of a mixed-method approach on quality assurance research. The next section presents the literature review of the study.

\section{Literature review}

This section presents, concept of research paradigm, major taxonomies of research paradigms, mixed approach and designs, and some of the reasons for applying mixed methods in assurance research. 


\subsection{The concept of research paradigm}

According to Mackenzie and Knipe [32] and Alghamdi [1], a research paradigm is the researcher's world of view or thinking or shared beliefs that inform the meaning and interpretation of research data. This means that it is a way through which the researcher uses to inform the world about his or her findings. While Kivunja and Kuyini [29] agree with Markenzie and Knipe[32], they further explain that a research paradigm is a conceptual lens through which the researcher assesses the methodological aspects of their studies to establish the research methods that will be used and how the data will be analyzed. From the view of the previous scholars, it seems that a research paradigm plays a major role in research as it determines the research design, methods of data collection, analysis, and interpretation. While the aforementioned scholars have provided the meaning of the research paradigm, Johnson and Onwuegbuzie [23], Nguyen[35], Kivunja and Kuyinin [29] a research paradigm is four major categories namely, epistemology, ontology, methodology, and axiology.

Epistemology refers to what leads us to know or getting knowledge about something or what is considered as knowledge within the world Kelly et al. [26]. In their view, the epistemology paradigm, the relationship between the nature of knowledge, the researcher, and what is to be a research problem under investigation is established. As it embarks more on knowledge, Suri [45] classifies the sources of knowledge into intuitive if the researcher bases his view on faith, beliefs, and intuition; authoritative knowledge if one based on data collected from people, books, leaders in an organization; if the basis is on knowledge obtained from sense experiences, demonstratable, objective facts then it is referred to as empirical epistemology. Consequently, if the basis of inquiry is reasoning as a way of getting reality then it is categorized as logical knowledge or rationalist epistemology. This means that through epistemology, the researcher can establish the authenticity of the data as he/she unveils knowledge in the context under investigation.

On the other hand, ontology is concerned with assumptions research makes to believe that the phenomenon under investigation is worthy in terms of reality and sensibility Scotland [43]. From the researcher's point of view, it helps to orient the research problem, its significance, and how you might approach it to contribute to its solution Kiyini and Kivunja [29] and Siddiqui [44]. Furthermore, it helps the researcher to determine the real nature or fundamental concepts that constitute themes on which data is analyzed to establish its meaning and sense.

Axiology is defined by Leonelli [31], Biddle and Schafft [3] as the ethical issues and considerations that are put in place while developing a study or research proposal. This means that it involves the type of respondents, the audience of the study, the data that will be collected, how they will be protected with aspects of confidentiality, and the value attached to them. In support of this, Martin et al. [33] points out that axiology involves strategies that will be used by the researcher to prevent psychological, political, and emotional harm. While elaborating on the views of Hartman [18], Kiyini and Kivunja[29] reviewed the literature by Rescher [41] who classifies research ethical considerations into mainly, Taleology criterion depicts the theory of molarity which refers to doing what is good and desirable so that the research results are meaningful a satisfy the intended audience. Deontology criterion is acknowledging that any action taken during the research process will have its consequences, intended to benefit the participants, the researcher, the scholarly community, and the public Thanh and Thanh [51]. The moral criterion involves the intrinsic values that will be upheld during the research, for instance, the research will analyze and interpret the data in a trustworthy way. Then the fairness criterion calls for researchers to act in a fair way to all the participants and to uphold their rights.

\subsection{Major taxonomies of research paradigms used in educational research}

Paradigms are classified by Kim [28] into four taxonomies namely positivist, interpretivism, and critical theory. In addition to the three, Eysenck [14], Teddlie and Tashakkori [50], Thanh and Thanh [51] provide another category which is the pragmatic paradigm that consists of an amalgamation of some of the aspects of those classified by Kim[28]. As this aim of this paper is not to discuss the full details of research paradigms, positivist, interpretivism, and pragmatism are discussed.

2.2.1 Positivist paradigm. As pointed out by Plé [28] it is honored as being a scientific method of investigation in which methods like experimentation, observation reason-based experience, are applied to explore knowledge and human understanding. Positivist paradigm has been further studied by other scholars such as Poni [39] and Taylor[49] who content that it strives to investigate, confirm and predict law-like patterns of behavior, and in the testing of theories or hypotheses. Technically, the positivist paradigm applies scientific concepts to generate or discover knowledge, for instance, this can be seen in studies that employ experimental, control groups and other numerical methods such as the pre- and post-tests to measure the accumulation of scores Taylor[49] and Rahi [40]. Supporters of the positivist paradigm employ objectivity, validity, and reliability, which can be used along with the 
triangulation of data, methods, theories Broom and Willis [5]. It aims at providing explanations and to make predictions based on measurable outcomes Kiyini and Kivunja [29] and Opie [37]. Because of these assumptions, the Positivist paradigm advocates the use of quantitative research methods as the bedrock for the researcher's ability to be precise in the description of the parameters and coefficients in the data that are gathered, analyzed and interpreted, to understand relationships embedded in the data analyzed Kiyini and Kivunja [29].

2.2.2. Interpretivist paradigm. This paradigm is rooted in the belief that understanding knowledge can be generated through understanding and interpreting concepts through the subject world of human experience Guba and Lincoln [16] and Rahi [40]. This means that researchers using this paradigm base on the total understanding of a concept and exploring this understanding of the world in which they live. In this paradigm, the researcher goes and interacts with the subjects and tries to unveil their experiences and then uses these experiences to construct the reality or explain his world of view. Basing on these views, this paradigm adopts a subjectivist epistemology (researcher makes meaning out of the data obtained through his interaction with the research subjects), a relativist ontology(the researcher believes that there is the existence of multiple realities which he explores and creates meaning out of them), a naturalist methodology(here the research acts as a participant-observer and utilizes the data gathered through interviews, discourses, text messages, and reflective sessions and balanced axiology( here the research applies fairness in handling the participants while ensuring equal opportunities for each to participate in the study Kekeya [25] and Creswell and Creswell[11].

2.2.3. Pragmatic paradigm. Proponents of pragmatism concur that creating or discovering knowledge or reality cannot be done by a single either qualitative or quantitative approach but by a combination of both approaches (Johnson et al., 2005). In support of the previous view, Yvonne Feilzer [54] and Rahi [40] elaborate that in this paradigm the weakness of one approach is counteracted by another approach hence contributing to the robustness of the study findings. The researchers are free to use both quantitative and qualitative approaches; the essential is to find the best techniques and procedure of research that solve the problem statement. As the world is becoming more complex, scholars such as Tashakkori and Teddlie [48] and Biesta[4] assert that there is need to provide methods of research that more practical and pluralistic approaches that could allow a combination of methods that in conjunction could shed light on the actual behavior of participants, the beliefs that stand behind those behaviors and the consequences that are likely to follow from different behaviors about a multifaceted phenomenon under investigation. In this way pragmatism advocates for the use of methods that can lead to a better understanding of practically and flexibly hence it doesn't rely on a philosophical stance but depicts relational epistemology, a non-singular reality ontology (in which all individuals have their way of understanding and interpreting their world of view), and value-laden axiology (researching that benefits all individuals by addressing their diverse views).

\subsection{Mixed methods approaches/designs}

The use of mixed methods design in research is of utmost importance as it may help researchers to improve the robustness of data collection as well as the study findings. On this note, scholars such as Creswell and Creswell [10], Leech and Onwuegbuzie [30], Hesse-Biber [19], Yang, Khoo-Lattimore and Arcadia [53] agree that implementation approach and prioritization of data collection should be considered as the most crucial steps while conducting a mixedmethods study. They further explain that the implementation approach spells out the sequence in which data is gathered this can consist of collecting data from different sources in a concurrent, simultaneous, or parallel arrangement. On the other hand, priority refers which approach the research considers as the major design that drives the study, here in some cases the qualitative or quantitative may be given a higher priority or both may have an equal priority or emphasis may be put on some definite characteristics of either approach. While appreciating the previous scholars, the researcher agrees with Teddlie and Tashakkori [48] who points out that the main factor in determining where the emphasis is to be situated is mainly the research questions which also dictate the theoretical, conceptual framework, literature review and finally enlighten the suitable research design and method of data collection. In addition to the views, mixedmethod designs can be divided into four designs: exploratory sequential; explanatory sequential, convergent, and fully integrated. These are provided in the following Table 1.

From Table 1, sequential mixed methods designs are divided into sequential exploratory in which the quantitative may follow the quantitative approach, so in the case, the qualitative is used for the pre-test of the study mainly for instrument development. And the explanatory mixed methods where researchers usually combine both qualitative and quantitative methods interactively and laterally in all stages of the research process. On the other hand, no sequential mixed methods design consists of convergent design in which data is collected and analyzed separately but may not be completed together but the results of 
one approach may or may not affect the result of the other approach.

Table 1. Categories of mixed methods designs

\begin{tabular}{|c|c|}
\hline Mixed method design & Definition \\
\hline \multicolumn{2}{|l|}{ Sequential designs } \\
\hline 1.Sequential exploratory design & $\begin{array}{l}\text { Qualitative data is } \\
\text { first collected and } \\
\text { analyzed, and } \\
\text { themes are used } \\
\text { to drive the } \\
\text { development of a } \\
\text { quantitative } \\
\text { instrument to } \\
\text { further explore } \\
\text { the research } \\
\text { problem. }\end{array}$ \\
\hline 2. Sequential explanatory design & $\begin{array}{l}\text { Here the } \\
\text { quantitative } \\
\text { method is used } \\
\text { initially to select } \\
\text { the participants } \\
\text { for the qualitative } \\
\text { approach. }\end{array}$ \\
\hline \multicolumn{2}{|l|}{ Nonsequential designs } \\
\hline 1. Convergent Design & $\begin{array}{l}\text { Here both } \\
\text { approaches are } \\
\text { used in parallel or } \\
\text { are both used } \\
\text { simultaneously. }\end{array}$ \\
\hline 2. Fully integrated design & $\begin{array}{l}\text { This where both } \\
\text { the qualitative } \\
\text { and quantitative } \\
\text { approaches are } \\
\text { mixed and } \\
\text { integrated into } \\
\text { each phase of the } \\
\text { study. }\end{array}$ \\
\hline
\end{tabular}

Sources: Caruth [7], Creswell and Plano Clark [8] and organized by the researcher

Furthermore, the various mixed methods design mentioned seem to differ in the order of data collection and analysis and how they integrated into the research process.

\subsection{Reasons for using mixed methods in quality assurance research}

A mixed-methods approach is useful to develop a better understanding of complex phenomena by triangulating or corroborating or complementing one set of results with another and thereby enhancing the validity of inferences Cameron and Miller [6], Mertens [33], Caruth [7] and Neal et al. [34]. Regarding quality assurance research, researchers prefer using mixed methods design basing on the fact that investigating quality assurance as a public policy and its practices is a complex and multifaceted process that involves the views of different actors and, the collection and analysis of data from different sources of which employing a single research approach may limit the comprehensiveness of the data and accuracy of the findings. In this case, quality assurance researchers can use mixed methods so as such that the strength of one method can counteract the weakness of another. According to Wisdom et al.[52] and Yvonne Feilze [54], researchers always use mixed methods for the following in the following ways and purposes: i)Triangulation (the quantitative and qualitative findings are compared); ii)Complementarity (the findings from one analysis are used to enhance or clarify the findings from another analysis i.e. quantitative analysis); iii) Development (data is collected sequentially and the findings from one analysis type are used to inform data collected and analyzed); vi) Initiation process (identifies the contradictions or paradoxes that might reframe the research question); v) expansion (quantitative and qualitative analyses are used to expand the study's scope). The purposes seem to suit the use of mixed methods in investigating quality assurance in education institutions as it helps the researchers to consolidate the various views provided by the diverse stakeholders such as the students, teachers, policymakers, employers, and parents. The use of mixed methods is also worthy to quality assurance research in that it helps the researchers to compare the findings obtained from both the qualitative with quantitative approaches as this will initiate, develop, expand the scope of the study through interpreting opinions emerging from the respondents in the various education settings.

\section{Methodology}

The systematic review applied the four quality criteria for mixed methods as defined by Creswell and Clark[10], Creswell and Plano Clark [8], Ivanova et al. [21] which include the following: i) Collection of both qualitative and quantitative data and mixing the sources of data, which serves as an indicator for rigor in data collection and analysis; use of mixed methods research design where each study was categorized in one of the six mixed methods designs; use of the terms which consistent with those used in mixed methods literature, here the studies were evaluated for whether they formerly recognized their study design as being a mixed-methods design e.g. Triangulation, mixed methods, multiple methods and words such as "qualitative and quantitative " used in the same sentence. 
Table 2. Studies included in the review

\begin{tabular}{|c|c|c|c|c|c|c|c|}
\hline Authors & Study & Methods & Country & Design & Integration & Paradigm & $\begin{array}{l}\text { Purpose of } \\
\text { mixed methods }\end{array}$ \\
\hline $\begin{array}{l}\text { 1.Augustus E. } \\
\text { Osseo-Asare, } \\
\text { David Long } \\
\text { bottom, } \\
\text { William D. } \\
\text { Murphy } \\
(2005)\end{array}$ & $\begin{array}{l}\text { Leadership } \\
\text { best practices } \\
\text { for sustaining } \\
\text { quality in UK } \\
\text { higher } \\
\text { education } \\
\text { from the } \\
\text { perspective } \\
\text { of the EFQM } \\
\text { Excellence } \\
\text { Model }\end{array}$ & $\begin{array}{l}\text { Questionnaires } \\
\text { Interviews }\end{array}$ & UK & $\begin{array}{l}\text { Sequential } \\
\text { exploratory } \\
\text { (qual } \rightarrow \text { QUAN) }\end{array}$ & $\begin{array}{l}\text { Data } \\
\text { interpretation }\end{array}$ & Positivism & Complementarity \\
\hline $\begin{array}{l}\text { 2.Antigoni Pa } \\
\text { padimitriou, } \\
\text { Don } \\
\text { F. Westerheij } \\
\text { den (2010) }\end{array}$ & $\begin{array}{l}\text { Adoption of } \\
\text { ISO-oriented } \\
\text { quality } \\
\text { management } \\
\text { system in } \\
\text { Greek } \\
\text { universities: } \\
\text { Reactions to } \\
\text { isomorphic } \\
\text { pressures }\end{array}$ & $\begin{array}{l}\text { Questionnaires } \\
\text { Interviews }\end{array}$ & Greece & $\begin{array}{l}\text { Sequential } \\
\text { exploratory } \\
(\text { qual } \rightarrow \text { QUAN) }\end{array}$ & $\begin{array}{l}\text { Data } \\
\text { interpretation }\end{array}$ & Positivism & Triangulation \\
\hline $\begin{array}{l}\text { 3.Christos } \\
\text { Vidalakis, } \\
\text { Ming Sun and } \\
\text { Aspasia Papa } \\
\text { (2013) }\end{array}$ & $\begin{array}{l}\text { The quality } \\
\text { and value of } \\
\text { higher } \\
\text { education } \\
\text { facilities: a } \\
\text { comparative } \\
\text { study }\end{array}$ & $\begin{array}{l}\text { Questionnaires } \\
\text { Interviews }\end{array}$ & UK & $\begin{array}{l}\text { Sequential } \\
\text { exploratory } \\
\text { (qual } \longrightarrow \text { QUAN) }\end{array}$ & $\begin{array}{l}\text { Data } \\
\text { interpretation }\end{array}$ & Positivism & Complementarity \\
\hline $\begin{array}{l}\text { 4.Jacqueline } \\
\text { Baumgart } \\
(2013)\end{array}$ & $\begin{array}{l}\text { The } \\
\text { Challenges of } \\
\text { Quality } \\
\text { Assurance in } \\
\text { Private } \\
\text { Higher } \\
\text { Education }\end{array}$ & $\begin{array}{l}\text { Questionnaires } \\
\text { Focus group } \\
\text { interviews }\end{array}$ & UK & $\begin{array}{l}\text { Sequential } \\
\text { exploratory } \\
\text { (qual } \rightarrow \text { QUAN) }\end{array}$ & $\begin{array}{l}\text { Data } \\
\text { interpretation }\end{array}$ & Positivism & Complementarity \\
\hline
\end{tabular}




\begin{tabular}{|c|c|c|c|c|c|c|c|}
\hline Internation & $\begin{array}{l}\text { urfalofistnnovative } \\
\text { Soututhons in } \\
\text { Southica }\end{array}$ & ss Strategies (IJBSS), V & e 6 , Issue 1 & & & & \\
\hline $\begin{array}{l}\text { 5.Ivanovna } \\
\text { (2013) }\end{array}$ & $\begin{array}{l}\text { Implementin } \\
\text { g Quality } \\
\text { Criteria in } \\
\text { Designing } \\
\text { and } \\
\text { Conducting a } \\
\text { Sequential } \\
\text { QUAN } \rightarrow \\
\text { QUAL } \\
\text { Mixed } \\
\text { Methods } \\
\text { Study of } \\
\text { Student } \\
\text { Engagement } \\
\text { with } \\
\text { Learning } \\
\text { Applied } \\
\text { Research } \\
\text { Methods } \\
\text { Online. }\end{array}$ & $\begin{array}{l}\text { Questionnaires } \\
\text { Interviews }\end{array}$ & USA & $\begin{array}{l}\text { Sequential } \\
\text { exploratory } \\
(\text { qual } \rightarrow \text { QUAN) }\end{array}$ & $\begin{array}{l}\text { Data } \\
\text { interpretation }\end{array}$ & Positivism & Complementarity \\
\hline $\begin{array}{l}\text { 6.Ronnie } \\
\text { Telford, } \\
\text { Ron Masson } \\
(2005)\end{array}$ & $\begin{array}{l}\text { The } \\
\text { congruence } \\
\text { of quality } \\
\text { values in } \\
\text { higher } \\
\text { education }\end{array}$ & $\begin{array}{l}\text { Focus group } \\
\text { discussion } \\
\text { Questionnaires } \\
\text { Interviews }\end{array}$ & UK & $\begin{array}{l}\text { Sequential } \\
\text { exploratory } \\
\text { (qual } \longrightarrow \text { QUAN) }\end{array}$ & $\begin{array}{l}\text { Data } \\
\text { interpretation } \\
\text { stage }\end{array}$ & Positivism & Triangulation \\
\hline $\begin{array}{l}\text { 7.Antigoni } \\
\text { Papadimitriou } \\
\text { (2017) }\end{array}$ & $\begin{array}{l}\text { Looking for } \\
\text { Clues about } \\
\text { Quality: A } \\
\text { Multilevel } \\
\text { Mixed } \\
\text { Design on } \\
\text { Quality } \\
\text { Management }\end{array}$ & $\begin{array}{l}\text { Questionnaires } \\
\text { Interviews } \\
\text { Documentation }\end{array}$ & Greece & $\begin{array}{l}\text { Concurrent } \\
\text { (QUAL+QUAN) }\end{array}$ & $\begin{array}{l}\text { Data } \\
\text { interpretation } \\
\text { Data analysis }\end{array}$ & Positivism & Complementarity \\
\hline
\end{tabular}




\begin{tabular}{|c|c|c|c|c|c|c|c|}
\hline Internatior & 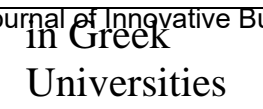 & ss Strategies (IJBSS), V & e 6 , Issue $1,2 C$ & & & & \\
\hline $\begin{array}{l}\text { 8.Chee Choy } \\
\text { (2017) }\end{array}$ & $\begin{array}{l}\text { Student's } \\
\text { perceptions } \\
\text { of quality } \\
\text { learning in a } \\
\text { Malaysian } \\
\text { university a } \\
\text { mixed- } \\
\text { method } \\
\text { approach }\end{array}$ & $\begin{array}{l}\text { Interview } \\
\text { Questionnaires }\end{array}$ & Malaysia & $\begin{array}{l}\text { Sequential } \\
\text { Exploratory } \\
\text { (QUAL } \rightarrow \text { QUAN) }\end{array}$ & $\begin{array}{l}\text { Data } \\
\text { interpretation } \\
\text { Data analysis }\end{array}$ & Positivism & Triangulation \\
\hline $\begin{array}{l}9 . \\
\text { Teeroovengad } \\
\text { um, } \\
\text { Kamalanabha } \\
\text { n, Seebaluck } \\
\text { (2014). }\end{array}$ & $\begin{array}{l}\text { Measuring } \\
\text { service } \\
\text { quality in } \\
\text { higher } \\
\text { education } \\
\text { Development } \\
\text { of a } \\
\text { hierarchical } \\
\text { model } \\
\text { (HESQUAL) }\end{array}$ & $\begin{array}{l}\text { Interviews } \\
\text { questionnaires }\end{array}$ & $\begin{array}{l}\text { Mauritiu } \\
\mathrm{s}\end{array}$ & $\begin{array}{l}\text { Sequential } \\
\text { Exploratory } \\
\text { (qual } \longrightarrow \text { QUAN) }\end{array}$ & $\begin{array}{l}\text { Data } \\
\text { interpretation }\end{array}$ & Positivism & Expansion \\
\hline $\begin{array}{l}\text { 10. Klorklear } \\
\text { et.al. (2012) }\end{array}$ & $\begin{array}{l}\text { Factors } \\
\text { affecting the } \\
\text { implementati } \\
\text { on of Quality } \\
\text { Assurance. }\end{array}$ & $\begin{array}{l}\text { Documentation } \\
\text { Questionnaires }\end{array}$ & UK & $\begin{array}{l}\text { Concurrent } \\
\text { (QUAL+QUAN) }\end{array}$ & $\begin{array}{l}\text { Interpretation } \\
\text { Data analysis }\end{array}$ & Positivism & Complementarity \\
\hline $\begin{array}{l}\text { 11.Pongo, } \\
\text { Asare, Abdul- } \\
\text { Fatahi } \\
\text { (2015). }\end{array}$ & $\begin{array}{l}\text { Challenges of } \\
\text { the 21st } \\
\text { Century on } \\
\text { Quality } \\
\text { Assurance. }\end{array}$ & $\begin{array}{l}\text { Interviews } \\
\text { questionnaires }\end{array}$ & Ghana & $\begin{array}{l}\text { Sequential } \\
\text { exploratory } \\
\text { (qual } \rightarrow \text { QUAN) }\end{array}$ & $\begin{array}{l}\text { Data analysis } \\
\text { Data } \\
\text { collection }\end{array}$ & Positivism & Complementarity \\
\hline $\begin{array}{l}\text { 12.Jacqueline } \\
\text { Baumgardt } \\
\text { (2013) }\end{array}$ & $\begin{array}{l}\text { Challenges of } \\
\text { Quality } \\
\text { Assurance in } \\
\text { Private }\end{array}$ & $\begin{array}{l}\text { Interviews } \\
\text { Questionnaires }\end{array}$ & $\begin{array}{l}\text { South } \\
\text { Africa }\end{array}$ & $\begin{array}{l}\text { Sequential } \\
\text { explanatory } \\
\text { (QUAL QUAN) }\end{array}$ & $\begin{array}{l}\text { Data } \\
\text { interpretation } \\
\text { Data analysis }\end{array}$ & $\begin{array}{l}\text { Constructi } \\
\text { vism }\end{array}$ & Triangulation \\
\hline
\end{tabular}




\begin{tabular}{|c|c|c|c|c|c|c|c|}
\hline \multicolumn{8}{|c|}{ International Jourhal of Innovative Bußiness Strategies (IJIBS), Volume 6, Issue 1, 2020} \\
\hline $\begin{array}{l}\text { 13. Arnold } \\
\text { Moyo and } \\
\text { Sothini } \\
\text { Natalia } \\
\text { Ngwenya } \\
(2018)\end{array}$ & $\begin{array}{l}\text { Service } \\
\text { quality } \\
\text { determinants. }\end{array}$ & $\begin{array}{l}\text { Focus group } \\
\text { discussion } \\
\text { Questionnaires }\end{array}$ & Kenya & $\begin{array}{l}\text { Sequential } \\
\text { exploratory } \\
\text { (qual QUAN) }\end{array}$ & $\begin{array}{l}\text { Data } \\
\text { interpretation }\end{array}$ & Positivism & Expansion \\
\hline $\begin{array}{l}\text { 14.Leiber, } \\
\text { Stensaker \& } \\
\text { Harvey } \\
(2016)\end{array}$ & $\begin{array}{l}\text { Impact } \\
\text { evaluation of } \\
\text { quality } \\
\text { assurance in } \\
\text { higher } \\
\text { education. }\end{array}$ & $\begin{array}{l}\text { Interviews } \\
\text { Questionnaires }\end{array}$ & Denmark & $\begin{array}{l}\text { Sequential } \\
\text { exploratory } \\
\text { (qual } \longrightarrow \text { QUAN) }\end{array}$ & $\begin{array}{l}\text { Data } \\
\text { Interpretation }\end{array}$ & Positivism & Complementarity \\
\hline $\begin{array}{l}\text { 15.Choiriyah, } \\
\text { Kumaidi, } \\
\text { Kartowagiran } \\
\text { (2018) }\end{array}$ & $\begin{array}{l}\text { Developing } \\
\text { Delta Internal } \\
\text { Quality } \\
\text { Assurance to } \\
\text { Evaluate the } \\
\text { Quality. }\end{array}$ & $\begin{array}{l}\text { Interview } \\
\text { Questionnaire }\end{array}$ & $\begin{array}{l}\text { Indonesi } \\
\text { a }\end{array}$ & $\begin{array}{l}\text { Sequential } \\
\text { exploratory } \\
(\text { qual } \rightarrow \text { QUAN) }\end{array}$ & $\begin{array}{l}\text { Data } \\
\text { interpretation }\end{array}$ & Positivism & Complementarity \\
\hline $\begin{array}{l}\text { 16.Evelyn } \\
\text { Chiyevo Garwe } \\
(2013)\end{array}$ & $\begin{array}{l}\text { Quality } \\
\text { assurance } \\
\text { challenges and } \\
\text { opportunities } \\
\text { faced by } \\
\text { private } \\
\text { Universities in } \\
\text { Zimbabwe }\end{array}$ & $\begin{array}{l}\text { Interviews } \\
\text { questionnaire }\end{array}$ & $\begin{array}{l}\text { Zimbabw } \\
\mathrm{e}\end{array}$ & $\begin{array}{l}\text { Sequential } \\
\text { Exploratory } \\
\text { (qual } \longrightarrow \text { QUAN) }\end{array}$ & $\begin{array}{l}\text { Data } \\
\text { interpretation }\end{array}$ & $\begin{array}{l}\text { Constructiv } \\
\text { ism }\end{array}$ & Triangulation \\
\hline $\begin{array}{l}\text { 17.Kagondu \& } \\
\text { Marwa } \\
(2017)\end{array}$ & $\begin{array}{l}\text { Quality Issues } \\
\text { in Kenya's } \\
\text { Higher } \\
\text { Education } \\
\text { Institutions } \\
\end{array}$ & $\begin{array}{l}\text { Interviews } \\
\text { questionnaire }\end{array}$ & Kenya & $\begin{array}{l}\text { Sequential } \\
\text { exploratory } \\
\text { (qual- QUAN) }\end{array}$ & $\begin{array}{l}\text { Data } \\
\text { interpretation }\end{array}$ & $\begin{array}{l}\text { Constructiv } \\
\text { ism }\end{array}$ & Triangulation \\
\hline
\end{tabular}




\begin{tabular}{|c|c|c|c|c|c|c|c|}
\hline Intern & $\begin{array}{l}\text { Qreaflityovative B } \\
\text { Assurance } \\
\text { Role in Public } \\
\text { Secondary } \\
\text { Schools in } \\
\text { Kenya }\end{array}$ & ss Strategies (IJIBS), & e 6, Issue 1, & & & & \\
\hline $\begin{array}{l}\text { 19. Mgaiwa } \\
\text { (2018) }\end{array}$ & $\begin{array}{l}\text { Examine the } \\
\text { extent of the } \\
\text { operationalizat } \\
\text { ion of quality } \\
\text { assurance } \\
\text { processes in } \\
\text { Tanzanian } \\
\text { Private } \\
\text { Universities } \\
\text { (PRUs). }\end{array}$ & $\begin{array}{l}\text { Interviews } \\
\text { Questionnaires } \\
\text { Documentary } \\
\text { review }\end{array}$ & Tanzania & $\begin{array}{l}\text { Concurrent } \\
\text { (QUAN+QUAL) }\end{array}$ & $\begin{array}{l}\text { Interpretation } \\
\text { Data analysis }\end{array}$ & Pragmatism & $\begin{array}{l}\text { Complementarity } \\
\text { Triangulation }\end{array}$ \\
\hline $\begin{array}{l}\text { 20.Moremo } \\
\text { (2017) }\end{array}$ & $\begin{array}{l}\text { QA Policies in } \\
\text { Adventist } \\
\text { secondary } \\
\text { schools in } \\
\text { Kenya }\end{array}$ & $\begin{array}{l}\text { Interviews } \\
\text { Questionnaires }\end{array}$ & Kenya & $\begin{array}{l}\text { Concurrent } \\
\text { (QUAN+QUAL) }\end{array}$ & $\begin{array}{l}\text { Data analysis } \\
\text { Data } \\
\text { interpretation }\end{array}$ & Positivism & Complementarity \\
\hline
\end{tabular}

Source: Literature

After obtaining the number of studies included in the review, the next section presents the findings of the study. 


\subsection{Inclusion criteria}

The systematic review of the literature was limited to only peer-reviewed journal articles written in English. A study was included if it met all the four inclusion criteria:

- The study was conducted in the education sector

- The study mixed qualitative and quantitative data

- The study discussed quality assurance issues in education.

- The study provided empirical evidence.

\subsection{Exclusion criteria}

- Theses were excluded

- Literature review papers

- Desktop research papers

\subsection{Search and selection of the studies}

While conducting the review, three search engines namely emerald insight, ERIC, and Google Scholar were used to identify articles in quality assurance research published in peer-reviewed journals. The major keywords employed in the search were: quality assurance and mixed methods, the mixed-methods approach in quality assurance research, quality assurance in education institutions, mixed methods approach and designs, and mixed methods designs in education research. The process of search and selection of the studies included in the study is shown in the following Figure 1.

From the initial search from the aforementioned databases, a total of 410 papers were identified as shown in Figure 1. After removal of duplicates, a total of 310 papers were identified. The papers were then subjected to two other consecutive screening stages. During the initial stage, the titles and abstracts were reviewed, and this excluded a total of 150 papers that were not in English, education, empirical studies, and not mixed methods resulting in 160 papers. The second stage, full-text articles were reviewed and 140 papers were removed due to not being on mixed methods in quality assurance and not mixed-method studies hence resulting in a total of 20 papers that were included in this study. The studies included in the study are shown in the following Table 2 .

\section{Findings of the study}

This section presents the findings of the study in terms of their characteristics.

\subsection{Characteristics of the mixed methods studies quality assurance}

This subsection presents the characteristics of the studies namely: paper(s) by country, study design, the purpose of using mixed methods and the research paradigm applied.

Table 3. Summary of characteristics of the included studies

\begin{tabular}{|l|c|c|c|}
\hline Characteristic & Number & Total & Percentage \\
\hline 1.Study(ies) by Country & 06 & 20 & 30 \\
\hline UK & 01 & 20 & 05 \\
\hline Denmark & 01 & 20 & 05 \\
\hline USA & 01 & 20 & 05 \\
\hline Greece & 01 & 20 & 05 \\
\hline Malaysia & 01 & 20 & 05 \\
\hline Indonesia & 01 & 20 & 05 \\
\hline Ghana & 01 & 20 & 05 \\
\hline South Africa & 01 & 20 & 05 \\
\hline Zimbabwe & 04 & 20 & 20 \\
\hline Kenya & 01 & 20 & 05 \\
\hline Mauritius & 01 & 20 & 05 \\
\hline Tanzania & 05 & 20 & 25 \\
\hline 2.Mixed methods designs & 14 & 20 & 70 \\
\hline Concurrent & \multicolumn{5}{|l|}{} \\
\hline $\begin{array}{l}\text { Sequential } \\
\text { exploratory }\end{array}$ & 01 & 20 & 05 \\
\hline $\begin{array}{l}\text { Sequential } \\
\text { explanatory }\end{array}$ & 01 & 20 & 85 \\
\hline 3. Purpose of applying mixed methods \\
\hline Triangulation & 06 & 20 & 30 \\
\hline Expansion & 03 & 20 & 15 \\
\hline Complementarity & 10 & 20 & 50 \\
\hline $\begin{array}{l}\text { Triangulation and } \\
\text { complementarity }\end{array}$ & 01 & 20 & 05 \\
\hline 4. Research paradigm adapted in the study \\
\hline Positivism & 17 & 20 & 05 \\
\hline Constructivism & 02 & 20 & \\
\hline Pragmatism & 01 & 20 & \\
\hline Source: a literatur| & \\
\hline
\end{tabular}

Source: a literature review

\section{Studies by country}

From Table 3, out of the 20 studies published in the peer-reviewed journals. These articles were read and reviewed and among them, it was observed that majority of studies were conducted in UK $6(30 \%)$ followed by Kenya in which 4 studies (20\%), other countries such as Denmark, USA, Greece, Malaysia, Indonesia, Ghana, South Africa, Zimbabwe, Mauritius and Tanzania in all of them one study $(5 \%)$ was identified. The summary of the studies is shown in the following Figure 2. 


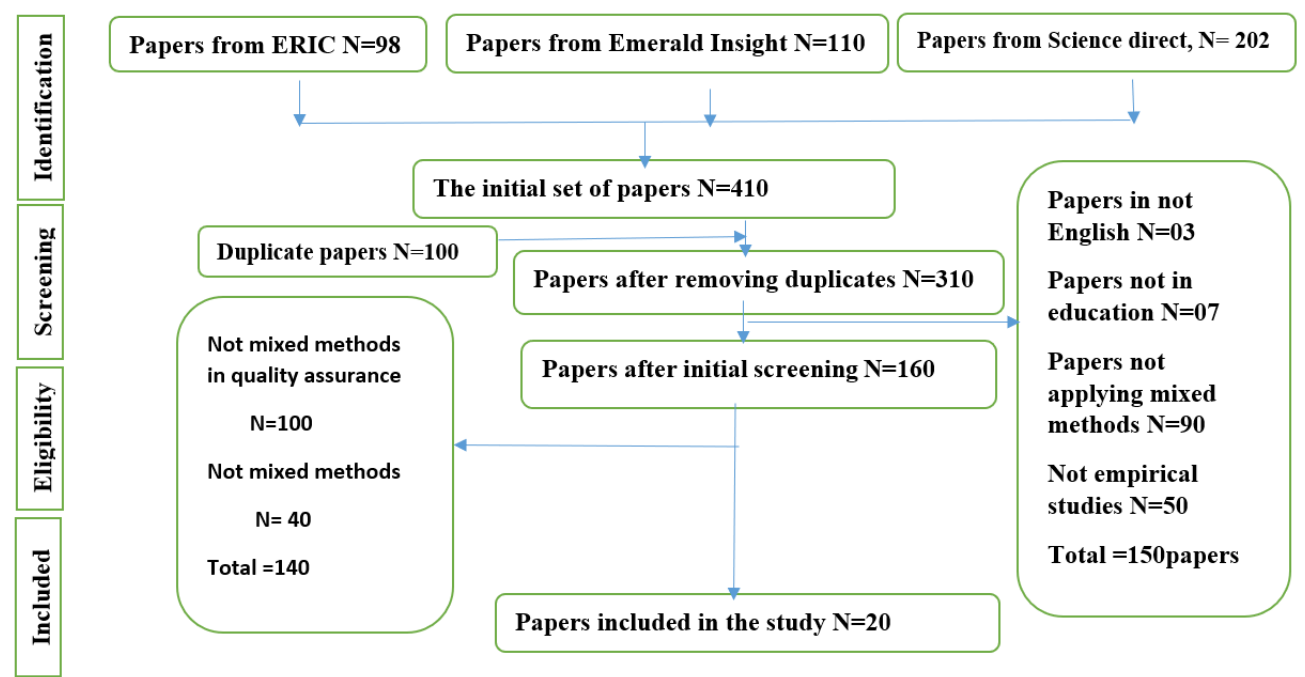

Figure 1. Summary of search criteria and selection of the included studies

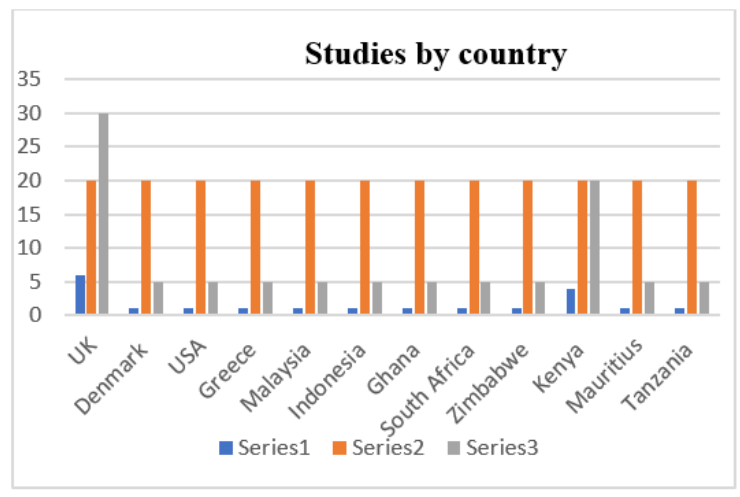

Figure 2. Summary of studies by country

How researchers apply Mixed methods designs/approaches in QA studies

\section{Mixed methods designs/approaches}

The mixed methods designs/approaches applied in QA studies are shown in Figure 3.

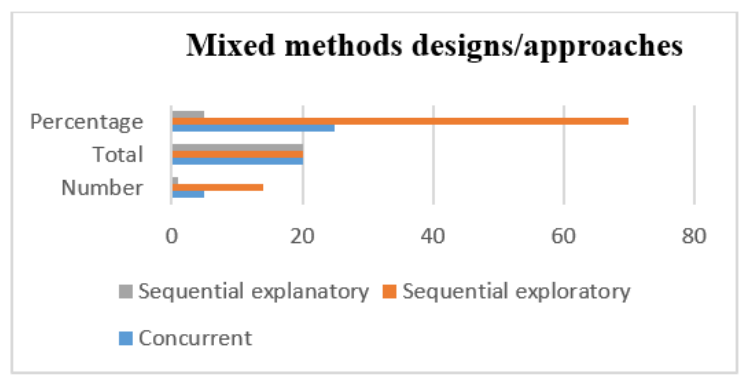

Source: a literature review

Figure 3. Summary mixed methods designs/approaches applied in QA studies
From Figure 3, five studies (25\%) applied concurrent mixed methods, 14 studies (70\%) employed sequential exploratory mixed methods while one study $(05 \%)$ used sequential mixed methods design or approach.

\section{Purpose of using mixed methods designs/approaches in QA studies}

From Figure 4, the purpose of applying mixed methods designs in the QA as identified from the studies. Here 10 studies out of $20(50 \%)$ applied mixed method designs for complementarity, 6 studies for triangulation (30\%) and 4studies (20\%) used them for expansion purposes. The summary of the purposes of applying mixed methods designs/approaches is shown in the following Figure 4.

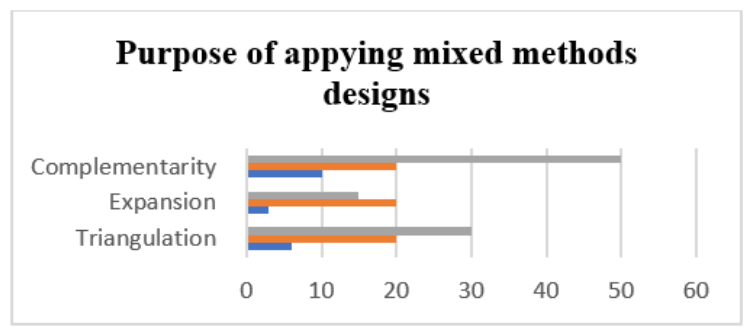

Figure 4. Summary of the purpose of using mixed methods designs/approaches in QA studies

\section{Research paradigm(s) applied in QA studies}

While conducting studies in QA, researchers applied mainly three research paradigms according to the following statistics: 17 studies (85\%) applied positivism, 2 studies (10\%) used constructivism and finally 1 study $(05 \%)$ applied pragmatism paradigm. 
The summary of the research paradigms applied in QA studies is shown in the following Figure 5.

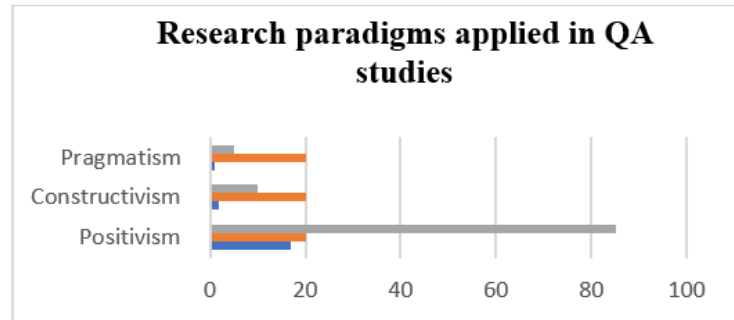

Figure 5. Summary of research paradigms applied in QA studies

After looking at the characteristics of the studies included in the review, the next section presents the discussion of the findings.

\section{Discussion of the findings}

In this section findings of the study about the research questions are presented.

\subsection{How the different researchers employed mixed methods in their studies}

Regarding on how the mixed methods have been applied in quality assurance research, as it is indicated in Table 3 and Figure 5, that most researchers applied sequential exploratory mixed method design in which they first collected qualitative data and then followed by the collection and analysis of quantitative data and here the quantitative approach was dominant. The purpose of this design was mainly expansion which according to [3], [4] is to extend the breadth and range of investigation through diverse methods of inquiry. The other purpose according to the review was complementarity in the interviews and focus groups were used for both construction of the questionnaire and also in the interpretation of the quantitative findings. The third reason for using this design was also triangulation in which one quantitative approach was used to confirm the findings from the qualitative one and vice versa. One study conducted by Baumgardt (2013) applied the explanatory mixedmethod design, in the researcher first collected quantitative data and later collected qualitative data and in the purpose was of expansion so that in-depth inquiry into the study was sought. On the other hand, the studies in which concurrent mixed-method design was used, the scholars collected both qualitative and quantitative data simultaneously. This was done for the aim of complementarity, triangulation, and expansion as mentioned in the previous studies). Regarding the integration of the qualitative and quantitative approaches, it was interestingly noted that among those who applied exploratory designs, out of the six studies three researchers mixed or integrated the approaches at data interpretation. While those who applied concurrent designs the integration was done at the data analysis and interpretation level. Then the study applied explanatory mixed design, integration was done at interpretation and data analysis levels (details are shown in Table 3).

\subsection{Approaches/designs applied in the identified studies in the review}

From Table 3 and Figure 3, it can be shown that among the 20 studies included in the review, 14 of them were applied sequential exploratory designs/approaches, 5 were sequential explanatory while 5 studies applied concurrent designs /approaches. The study, therefore, indicated that sequential exploratory designs/approaches were more prevalent than the sequential explanatory and concurrent designs/approaches. This systematic review of the literature demonstrates that quality assurance researchers are highly interested in applying research designs/ approaches that are invaluable in answering research questions that reflect both the qualitative and quantitative research questions in one study. Literature increasingly recognizes that single methods either quantitative or qualitative alone may be inadequate in capturing fully the perceptions, attitudes, and understanding of the complexity of quality assurance by the various respondents in educational institutions. Therefore, the research underpinned by these mixed methods designs/approaches provides a better way of studying complex, unstable, non-linear changes that are anticipated and depicted while studying quality assurance in educational institutions.

\subsection{How the paradigm(s) are conceptualized in the identified studies in the review}

The findings of the review indicated (in Table 3 and Figure 5) that although researchers applied mixed methods, the positivist dominated the investigations, followed by the constructivist and finally the pragmatic paradigm. Epistemologically in these studies, the researchers using the positivist paradigm were looking at establishing the nature of knowledge regarding quality assurance in terms of perceptions/attitudes, achievements, and challenges. Ontologically, the researchers regarded the knowledge of the respondents on quality assurance as being static and fixed according to the principal objective truth. Methodologically, in this paradigm the major method of data collection was a questionnaire survey (quantitative approach) but used the interviews/focus group discussion) for exploratory purposes. This was followed by the dominance of the constructivist paradigm as 
compared to the positivist approach in one study. Epistemologically, here the researchers believed that while investigating quality assurance there is a variety of interpretations regarding understanding nature and how quality assurance is implemented, the perceptions /attitudes, and challenges among the various respondents. This is also in line with Cameron and Miller [6] and Caruth [7] who assert that in constructivism the researcher relies upon the respondents' views of the situation investigation and recognizes the impact of the research on their background and experiences. Ontologically, the researchers believed that the respondents' knowledge about quality assurance regarding the perceptions, /attitudes, implementation, and challenges is subjective and reliable to changes in various contexts. So, in this situation, the quantitative approach was mainly used for sampling purposes and then the interviews/focus group discussion were the main methods of data collection.

And then the pragmatic paradigm was less applied in the identified studies for the review. In this case, the researchers collected and interpreted both qualitative and quantitative data simultaneously. Epistemologically, the researchers believe understanding quality assurance requires a variety of methods applied at the same time in a single study to ascertain the truth and reality occurring in terms of implementation, challenges; perceptions and attitudes regarding quality assurance in educational institutions, in this case, the notion of rational epistemology is portrayed. This is also further supported by Creswell, John W., and Clark [10] and Denscombe [13] who contend that the pragmatic paradigm puts emphasis on the problem under investigation as central and applies all approaches to its understanding. Also, Mackenzie and Knipe[32] point out that apart from the research problem being critical, the research questions, data collection, and analysis methods are also important and are selected in such a way to provide insights into the question with no philosophical loyalty to any alternative paradigm. In ontological terms, the researchers believe in flexibility while investigating QA in education institutions since due to its complexity no one approach can be fully used in a study. By this, the pragmatic paradigm does not rely on any stance and is a non-singular reality ontology (in which all individuals have their way of understanding and interpreting their world of view). Methodologically, here the researchers used both methods to collect the data simultaneously as well as in analyzing and interpreting it.

\section{Conclusion}

In the current systematic review of the literature on mixed methods approaches applied in quality assurance research, a total of 20 studies were identified in peer-reviewed journals published between 2005 and 2019. This paper argues that to create a better understanding of the phenomenon of quality assurance in education institutions, there should be an engagement in discussions regarding the epistemological and methodological designs/approaches related to the nature of the knowledge, quality assurance researchers in education research seek to create.

Developing an increased awareness of the mixed methods approaches and how the paradigms are conceptualized within the field of quality assurance in education is important because there is need to demonstrate the significance of implementing quality assurance and ensuring quality education basing on a critical understanding of the nature of knowledge itself at an empirical level. From this review, it was concluded that, although there is a general increase in the use of mixed methods approaches in other fields, it's yet to be deeply applied in quality assurance research in educational institutions.

\section{References}

[1] Alghamdi, S. (2015). Analyzing paradigmatic influences in particular research. International Journal of Humanities and Social Science, 5(8), 78-83.

[2] Beerkens, M. (2018). Evidence-based policy and higher education quality assurance: Progress, pitfalls, and promise. European Journal of Higher Education, 8(3), 272-287.

[3] Biddle, C., \& Schafft, K. A. (2015). Axiology and anomaly in the practice of mixed methods work Pragmatism, valuation, and the transformative paradigm. Journal of Mixed Methods Research, 9(4), 320-334.

[4] Biesta, G. (2010). Pragmatism and the philosophical foundations of mixed methods research. Sage Handbook of Mixed Methods in Social and Behavioral Research, 2, 95118.

[5] Broom, A., \& Willis, E. (2007). Competing paradigms and health research. Researching Health: Qualitative, Quantitative, and Mixed Methods, 16-30.

[6] Cameron, R., \& Miller, P. (2007). Mixed methods research: Phoenix of the paradigm wars. 21st Annual Australian \& New Zealand Academy of Management (ANZAM) Conference.

[7] Caruth, G. D. (2013). Demystifying mixed methods research design: A review of the literature. Online Submission, 3(2), 112-122.

[8] Creswell, J., \& Plano Clark, V. (2011). Designing and Conducting Mixed Methods Research. (SAGE Publications: Thousand Oaks, CA, USA).

[9] Creswell, J. W. (2007). Creswell and Plano Chapter 4 Mixed Methods Designs. Pdf. Applied Linguistics, 2. 
[10] Creswell, John W., \& Clark, V. L. P. (2017). Designing and conducting mixed methods research. Sage publications.

[11] Creswell, John W., \& Creswell, J. D. (2005). Mixed methods research: Developments, debates, and dilemmas. Research in Organizations: Foundations and Methods of Inquiry, 315-326.

[12] Creswell, John W., \& Creswell, J. D. (2017) Research design: Qualitative, quantitative, and mixed methods approach. Sage publications.

[13] Denscombe, M. (2008). Communities of practice: A research paradigm for the mixed methods approach. Journal of Mixed Methods Research, 2(3), 270-283.

[14] Eysenck, H. J. (1991). Dimensions of personality: 16, 5 , or 3? - Criteria for a taxonomic paradigm. Personality and Individual Differences, 12(8), 773-790.

[15] Geda, A. G. (2014). Quality assurance policy and practice in higher education institutions in Ethiopia [Ph.D. Thesis].

[16] Guba, E. G., \& Lincoln, Y. S. (1994). Competing paradigms in qualitative research. Handbook of Qualitative Research, 2(163-194), 105.

[17] Haris, A., Washizaki, H., \& Fukazawa, Y. (2018). Systematic Review of Utilized ICTs in Quality Assurance and Accreditation of Higher Education and a Case Study of Developing Country. EAI Endorsed Transactions on ELearning, 5(18).

[18] Hartman, R. S. (2011). The structure of value: Foundations of scientific axiology. Wipf and Stock Publishers.

[19] Hesse-Biber, S. (2010). Qualitative approaches to mixed methods practice. Qualitative Inquiry, 16(6), 455468.

[20] Imbulgoda, C. (n.d.). Compliance towards Quality Assurance System in Higher Education: A Systematic Literature Review.

[21] Ivankova, N. V., Creswell, J. W., \& Stick, S. L. (2006). Using mixed-methods sequential explanatory design: From theory to practice. Field Methods, 18(1), 320.

[22] Johnson, R. B., Onwuegbuzie, A. J., \& Turner, L. A (2005). Mixed methods research: Is there a criterion of demarcation. Annual Meeting of the American Educational Research Association, Montreal, Canada.

[23] Johnson, R. Burke, \& Onwuegbuzie, A. J. (2004). Mixed methods research: A research paradigm whose time has come. Educational Researcher, 33(7), 14-26.

[24] Kahsay, M. N. (2012). Quality and quality assurance in Ethiopian higher education: Critical issues and practical implications.
[25] Kekeya, J. (2019). The commonalities and differences between research paradigms. Contemporary PNG Studies, $31,26$.

[26] Kelly, G. J., McDonald, S., \& Wickman, P.-O. (2012). Science learning and epistemology. In Second international handbook of science education (pp. 281291). Springer.

[27] Khalil, M. M. (2017). Drivers of quality assurance implementation in higher education: The case of Lebanese private business schools [Ph.D. Thesis]. Staffordshire University.

[28] Kim, S. (2003). Research paradigms in organizational learning and performance: Competing modes of inquiry. Information Technology, Learning, and Performance Journal, 21(1), 9.

[29] Kivunja, C., \& Kuyini, A. B. (2017). Understanding and applying research paradigms in educational contexts. International Journal of Higher Education, 6(5), 26-41.

[30] Leech, N. L., \& Onwuegbuzie, A. J. (2009). A typology of mixed methods research designs. Quality \& Quantity, 43(2), 265-275.

[31] Leonelli, S. (2005). Pluralism and normativity in interdisciplinary research. Graduate Journal of Social Science, 2(1), 1.

[32] Mackenzie, N., \& Knipe, S. (2006). Research dilemmas: Paradigms, methods, and methodology. Issues in Educational Research, 16(2), 193-205.

[33] Mertens, D. M. (2010). Philosophy in mixed methods teaching: The transformative paradigm as illustration. International Journal of Multiple Research Approaches, 4(1), 9-18.

[34] Neal, M. B., Hammer, L. B., \& Morgan, D. L. (2006). Using Mixed Methods in Research Related to Work and Family.

[35] Nguyen, T. T. L. (2019). Selection of Research Paradigms in English Language Teaching: Personal Reflections and Future Directions. KnE Social Sciences, $1-19$.

[36] Niglas, K. (2009). How the novice researcher can make sense of mixed methods designs. International Journal of Multiple Research Approaches, 3(1), 34-46.

[37] Opie, C. (2004). What is educational research? Doing Educational Research. A Guide to First-Time Researchers. London: Sage Publications.

[38] Plé, B. (2000). Auguste Comte on positivism and happiness. Journal of Happiness Studies, 1(4), 423-445.

[39] Poni, M. (2014). Research paradigms in education. Journal of Educational and Social Research, 4(1), 407.

[40] Rahi, S. (2017). Research design and methods: A systematic review of research paradigms, sampling issues, 
and instrument development. International Journal of Economics \& Management Sciences, 6(2), 1-5.

[41] Rescher, N. (2013). Value matters: Studies in axiology (Vol. 8). Walter de Gruyter.

[42] Saketa, K. N. (2014). Quality assurance practices in Ethiopian public and private higher education institutions [Ph.D. Thesis]. The University of South Africa.

[43] Scotland, J. (2012). Exploring the philosophical underpinnings of research: Relating ontology and epistemology to the methodology and methods of the scientific, interpretive, and critical research paradigms. English Language Teaching, 5(9), 9-16.

[44] Siddiqui, S. (2019). Research paradigms: Their assumptions and relevance. International Journal of Research in Social Sciences, 9(5), 254-265.

[45] Suri, H. (2013). Epistemological pluralism in research synthesis methods. International Journal of Qualitative Studies in Education, 26(7), 889-911.

[46] Tan, A. H. T., Muskat, B., \& Zehrer, A. (2016). A systematic review of the quality of student experience in higher education. International Journal of Quality and Service Sciences.

[47] Tashakkori, A., \& Creswell, J. W. (2007). Exploring the nature of research questions in mixed methods research. Sage Publications Sage CA: Los Angeles, CA.

[48] Tashakkori, A., \& Teddlie, C. (2010). Sage handbook of mixed methods in social \& behavioral research. sage.

[49] Taylor, P. C. (2014). Contemporary qualitative research: Toward an integral research perspective. In Handbook of Research on Science Education, Volume II (pp. 52-68). Routledge.

[50] Teddlie, C., \& Tashakkori, A. (2006). A general typology of research designs featuring mixed methods. Research in the Schools, 13(1), 12-28.

[51] Thanh, N. C., \& Thanh, T. T. (2015). The interconnection between the interpretivism paradigm and qualitative methods in education. American Journal of Educational Science, 1(2), 24-27.

[52] Wisdom, J. P., Cavaleri, M. A., Onwuegbuzie, A. J., \& Green, C. A. (2012). Methodological reporting in qualitative, quantitative, and mixed methods health services research articles. Health Services Research, 47(2), $721-745$

[53] Yang, E. C. L., Khoo-Lattimore, C., \& Arcodia, C. (2017). A systematic literature review of risk and gender research in tourism. Tourism Management, 58, 89-100.

[54] Yvonne Feilzer, M. (2010). Doing mixed methods research pragmatically: Implications for the rediscovery of pragmatism as a research paradigm. Journal of Mixed Methods Research, 4(1), 6-16. 